\title{
移流拡散方程式の高精度差分近似法・OPTIMAL スキームの開発 \\ PROPOSAL OF OPTIMAL SCHEME FOR HIGHLY ACCURATE FINITE-DIFFERENCE APPROXIMATION METHOD OF CONVECTION DIFFUSION EQUATIONS
}

\author{
松尾陽*, 李政宰**, 倉㴊 隆***, 鎌田元康****
} Yoh MATSUO, Jurng-Jae YEE, Takashi KURABUCHI and Motoyasu KAMATA

A novel OPTIMAL scheme based on the second-order interpolation tecnique is proposed for highly accurate and non-oscillatory simulation of convection. The effectiveness of this scheme is demonstrated through applications of several scalar transport problems in two-dimensional laminar and turbulent recirculating flow.

The results are compared to currently avaiable schemes such as PLDS, QUICK, LODA, ULTRASHARP etc., and these results demonstrate that the bounded OPTIMAL and the bounded LODA with local full upwinding can give accurate and wiggle free solutions with properly designed coarse mesh layout. However, the OPTIMAL evidently appears advantageous for practical applications because of its computational simplicity and stable convergent process.

Keywords: OPTIMAL scheme, second-order interpolation, finite-difference method, non-oscillatory, $k-\varepsilon$ turbulent model, scalar transport equation

OPTIMAL スキーム， 2 次精度近似法, 有限差分法, 非振動, $k-\varepsilon$ モデル, スカラー輸送方程式

\section{1. 粕曹}

温度・濃度等に関するスカラー輸送方程式の差分解を 求める場合, 計算領域の大半で生産項が 0 となる条件が 多いことから，移流項に高精度スキームを用いることが 全般的な精度の向上に有効と考えられる。しかし，2次 精度スキームは一般に”wiggling"や非現実的な負の濃度 等の問題を伴うため, 実用計算では数值拡散の混入を承 知の上で 1 次風上系のスキームが広く用いられている1)。 この問題に対処するため, これまで大別して, LODA 法 $^{2}$ に代表される QUICK スキーム光と1 次風上スキー ムをブレンドする手法年や ULTRA-SHARP スキーム5) のように 2 次風上系のスキームを変数の局所分布に応じ て使い分ける手法等が”wiggling”等の振動を回避する高 精度差分近似スキームとして提案されている。前者は部 分的な人工拡散の導入に相当し, 後者は差分スキームが 本質的に非線形化することを意味する。

LODA 法は, 基本差分式をQUICK スキームとし，コ ントロール・ボリューム(以下, CV) 界面内㨉值に 1 次風 上スキームとの加重平均を用い，安定性を向上させてい
るが, 実際計算に用いると、スキームの最適化は問題に 依存することになるため; スキームのチューニングは経 験に頼らざるを得ない。一方, ULTRA-SHARP スキー 厶では, CV 界面付近の局所変数分布より, 中心差分, QUICK， 2 次風上差分スキームを選択する方式である が，本質的に非線形スキームになるため，一般に収束性 が悪い。

筆者らは以上の点について検討を進めた結果， CV 界 面の内㨉値に 2 次風上系スキームの内挿法を一貫して用 いるか，風上因子を局所セルペクレ数によって最適化す ることで, 2 次精度スキームに特徴的な” wiggling”等の 問題を大幅に緩和可能な新たなスキーム(Oscilation Preventing Technical algorithm based on the second-order Interpolation Method for Advection Linked convection, 以下，OPTIMAL スキームと略称）を開発した。本論文 では, OPTIMAL スキームを中心にこれらのスキームの 概念, 特性について述へるとともに, 各スキームの精度 や特性を 2 次元定常/非定常濃度拡散問題を対象に検討 した結果について報告する。

\footnotetext{
* 東京大学工学部建学科教授・工博

** 果京大学工学部建策学科 大学院生・工修

*** 東京理科大学工学部建築学科 請師. 工博

**** 東京大学工学部建築学科助教授・工博

Prof., Dept. of Architecture, Faculty of Engineering, University of Tokyo, Dr. Eng. Graduate Student, Dept. of Architecture, Faculty of Engineering, University of Tokyo, M. Eng. Lecturer, Dept. of Architecture, Faculty of Engineering, Science University of Tokyo, Dr. Eng. Assistant Prof., Dept. of Architecture, Faculty of Engineering, University of Tokyo, Dr. Eng.
} 


\section{2. 高精度差分スキームの概要}

\section{1 一般型 2 次風上系スキーム}

受動的スカラー輸送方程式の基礎式はテンソル表記を 用いると，以下のようになる。

$\frac{\partial \phi}{\partial t}=-\frac{\partial u_{j} \phi}{\partial x_{j}}+\frac{\partial}{\partial x_{j}}\left(\Gamma_{\phi} \frac{\partial \phi}{\partial x_{j}}\right)+S_{\phi}$

図 1 に示す 1 次元定常の流れを考えると，CV 界面に おける 2 次風上系スキームの内㨀值は，風上側空間分布 の曲率因子 (Curvature-Factor，以下 CF) を導入すれば 以下のように一般的に表現できる。

$\phi_{w}=\frac{1}{2}\left(\phi_{P}+\phi_{W}\right)-C F\left(\phi_{P}-2 \phi_{W}+\phi_{W W}\right),\left(u_{w} \geq 0\right)(2)$

$\phi_{e}=\frac{1}{2}\left(\phi_{E}+\phi_{P}\right)-C F\left(\phi_{E}-2 \phi_{P}+\phi_{W}\right) \quad,\left(u_{e} \geq 0\right)$

ここで $\mathrm{CF}=0$ は中心差分, $\mathrm{CF}=0.125$ は $\mathrm{QUICK}, \mathrm{CF}=$ 0.5 は 2 次精度風上差分スキームである。この 2 次風上 系スキームを図 1 の記号により離散化すると，以下のよ うな 5 点離散化方程式となり。

$a_{P} \phi_{P}=a_{E} \phi_{E}+a_{W} \phi_{W}+a_{E E} \phi_{E E}+a_{S S} \phi_{S S}+b$

離散化式の各セルの係数を整理すると、下式となる。

$a_{W}=D_{w}+(0.5-C F) u_{w}^{-}+(0.5+2 C F) u_{w}^{+}+(C F) u_{e}^{+}$

$a_{E}=D_{e}-(0.5-C F) u_{e}^{+}-(0.5+2 C F) u_{e}^{-}-(C F) u_{w}^{-}$

$a_{W W}=-(C F) u_{w}^{+}$

$a_{E E}=(C F) u_{e}^{-}$

式 5)〜8) から分かるように，中心差分でセルペクレ数 が 2 以下の場合を除き，いずれかの係数が負となるため 解の単調性は保証されない。

\subsection{LODA 法}

LODA 法は, 基本差分近似式を QUICK スキームと し，CV 界面の内㨉値に 1 次風上スキームとの加重平均 を用いることで安定性を向上させる方法である。つまり， 内㨉式を下式とし ${ }^{2), 6)}$,

$\phi_{i}^{\mathrm{LODA}}=\gamma_{i} \phi_{i}^{\mathrm{QUICK}}+\left(1-\gamma_{i}\right) \phi_{i}^{\text {first upwind }}$

式 4)の各セルの係数を求めれば以下になる。

$a_{W}=D_{w}+\frac{3}{8} \gamma_{w} u_{w}^{-}+\frac{6}{8} \gamma_{w} u_{w}^{+}+\frac{1}{8} \gamma_{e} u_{e}^{+}+\left(1-\gamma_{w}\right) u_{w}^{+}$

$a_{E}=D_{e}-\frac{3}{8} \gamma_{e} u_{e}^{+}-\frac{6}{8} \gamma_{e} u_{e}^{-}-\frac{1}{8} \gamma_{w} u_{w}^{-}-\left(1-\gamma_{e}\right) u_{e}^{-}$

$a_{W W}=-\frac{1}{8} \gamma_{w} u_{w}^{+}$

$a_{E E}=\frac{1}{8} \gamma_{e} u_{e}^{-}$
〈祀奇>
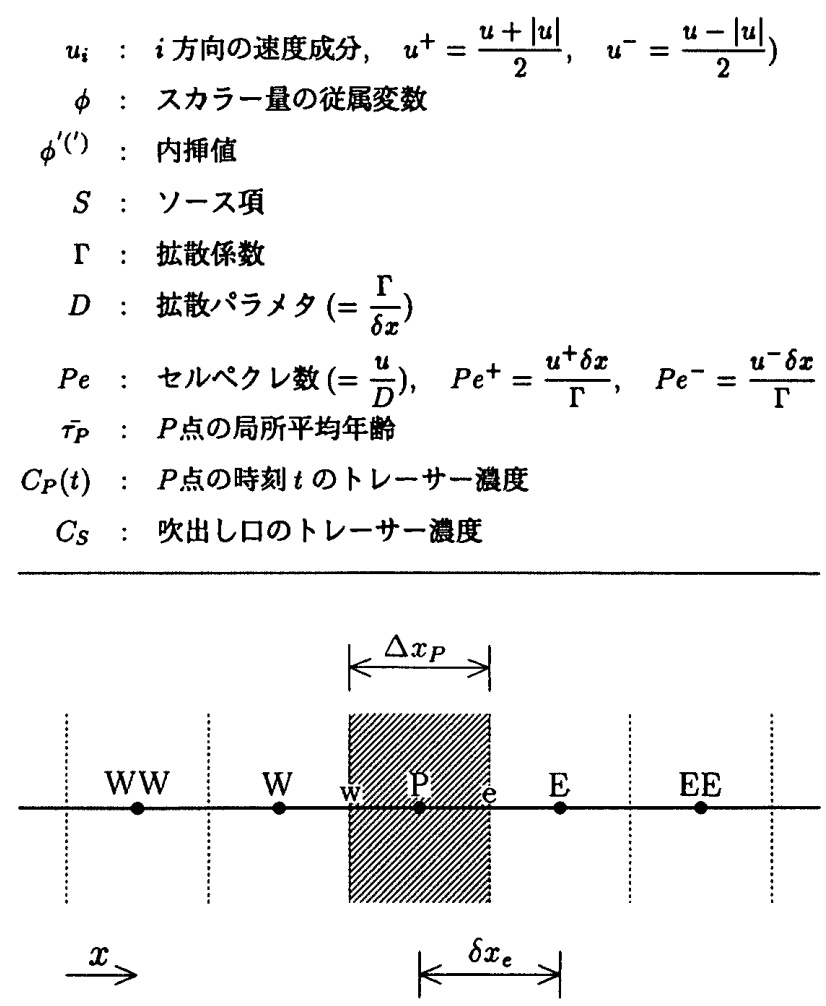

図 1 離散化コントロール・ボリュームの定義点

LODA では，P セルに隣接する W,E セルに注目し， $a_{W}, a_{E}$ が正あるいはぜロになるように加重係数を求め る。 $u_{w}, u_{e}$ が同一風向とすればその条件は以下となる。

$\gamma_{w}=\min \left(1, \frac{8}{3\left|\mathrm{Pe}_{\mathbf{w}}\right|}\right) \quad,\left(\mathrm{u}_{\mathrm{w}}<0\right)$

$\gamma_{e}=\min \left(1, \frac{8}{3\left|\mathrm{Pe}_{\mathrm{e}}\right|}\right) \quad,\left(\mathrm{u}_{\mathrm{e}}>0\right)$

なお，LODA 法をそのまま用いると計算が搪散過大と なるため，解の許容範囲を予め $\phi_{\min } \leq \phi \leq \phi_{\max }$ と指定 し注 1)，この範囲を逸脱する部分のみに LODA 法を選 択的に適用する場合がある。しかしここの伡容範囲は一 定ではなく問題に強く依存しており，スキーム最適化は 経験によるしかないのがこのスキームの欠点である。本 論文ではこれらを条件付／無条件 LODA と区別するが, 条件付 LODA は非線形となる。

\subsection{ULTRA-SHARP スキーム}

ULTRA-SHARP スキームは CV 界面付近の局所变数 分布より, 中心差分, QUICK, 2 次精度風上差分を使い 分けるスキームである。図 2 の記号を用い，Uから $D$ 点

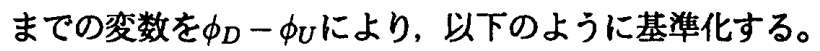
$\tilde{\phi}(x)=\frac{\phi(x)-\phi_{U}}{\phi_{D}-\phi_{U}}$

この基準化変数を用い, ULTRA-SHARP スキームでは 以下の内挿式を用いる。 


$$
\begin{array}{ll}
\tilde{\phi}_{f}=\frac{3}{2} \tilde{\phi}_{C} \quad,\left(\tilde{\phi}_{C}<0\right) \\
\tilde{\phi}_{f}=\frac{3}{4} \tilde{\phi}_{C}+\frac{3}{8} \quad,\left(0 \leq \tilde{\phi}_{C}<\frac{5}{6}\right) \\
\tilde{\phi}_{f}=1 \quad, \quad\left(\frac{5}{6} \leq \tilde{\phi}_{C}<1\right) \\
\tilde{\phi}_{f}=\frac{1}{2} \tilde{\phi}_{C}+\frac{1}{2} \quad,\left(1 \leq \tilde{\phi}_{C}\right)
\end{array}
$$

対応する離散化方程式の係数は以下のように表される。 $a_{W}=D_{w}+\left(0.5-C F_{w}^{-}\right) u_{w}^{-}+\left(0.5+2 C F_{w}^{+}\right) u_{w}^{+}+\left(C F_{e}^{+}\right) u_{e}^{+}(21)$ $a_{E}=D_{e}-\left(0.5-C F_{e}^{+}\right) u_{e}^{+}-\left(0.5+2 C F_{e}^{-}\right) u_{e}^{-}-\left(C F_{w}^{-}\right) u_{w}^{-}(22)$

$a_{W W}=-\left(C F_{w}^{+}\right) u_{w}^{+}$

$a_{E E}=\left(C F_{e}^{-}\right) u_{e}^{-}$

ここに CF は CV 界面に関する変数であり以下となる。

$C F\left(\tilde{\phi}_{C}\right)=\frac{1+\tilde{\phi}_{C}-\tilde{\phi}_{f}}{2 \cdot\left(1-2 \tilde{\phi}_{C}\right)}$

\section{OPTIMAL スキーム}

\subsection{OPTIMAL スキームの概要}

新開発 OPTIMAL スキームは, 前述した一般型 2 次 風上系スキームの内㨉法を一貫して使用するが, $\mathrm{CF}$ を 変数として 1 次風上スキームとブレンドなしに，セルペ クレ数の分布状況に応じて最も適切に選ぶスキームであ る。つまり，式 5) 8) の一般型 2 次風上系のスキーム の離散化方程式の係数を，CF を変数として，セルペク レ数を用いて以下のように変形する。

$$
\begin{gathered}
a_{W}=\frac{\Gamma_{w}}{\delta x_{w}}\left\{\begin{array}{l}
\left(0.5+2 C F_{w}\right) P e_{w}^{+}+\left(0.5-C F_{w}\right) P e_{w}^{-} \\
+\left(C F_{e}\right) \frac{\delta x_{w} u_{e}^{+}}{\Gamma_{w}}+1
\end{array}\right\} \\
a_{E}=\frac{\Gamma_{e}}{\delta x_{e}}\left\{\begin{array}{l} 
\\
-\left(0.5+2 C F_{e}\right) P e_{e}^{-}-\left(0.5-C F_{e}\right) P e_{e}^{+} \\
-\left(C F_{w}\right) \frac{\delta x_{e} u_{w}^{-}}{\Gamma_{e}}+1
\end{array}\right\}
\end{gathered}
$$

$a_{W W}=-C F_{w} u_{w}^{+}$

$a_{E E}=C F_{e} u_{e}^{-}$

ここで, OPTIMAL スキームは隣接セルの係数 $a_{W}, a_{E}$ が $a_{W}, a_{E} \geq 0$ となるようにCF 求めて計算を行う。つ まり, LODA と同様に CV 界面上の速度 $u_{e}, u_{w}$ が同一符 号と仮定した上，式 26)，27）が $a_{W}, a_{E} \geq 0$ となるよう に式を連立させて解くと， CF は次のようになる。

$C F_{w} \leq \frac{1}{2}+\frac{1}{P e_{w}^{\bar{w}}} \quad,\left(u_{w}<0\right)$

$C F_{e} \geq \frac{1}{2}-\frac{1}{P e_{e}^{+}} \quad,\left(u_{e} \geq 0\right)$

更に，式 28)，29）の $a_{W W}, a_{E E}$ はいずれか負または 0 となるので，これらの係数の絶対值が最小となる条件を

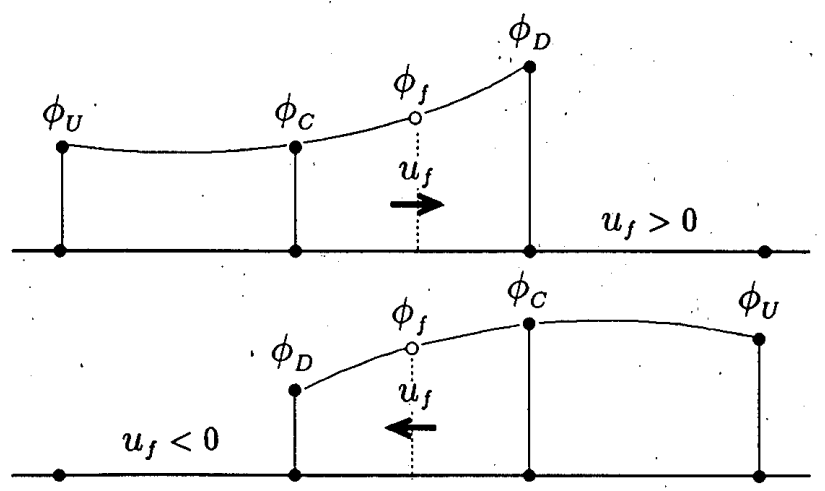

図 2 ULTRA-SHARP スキームの定義点

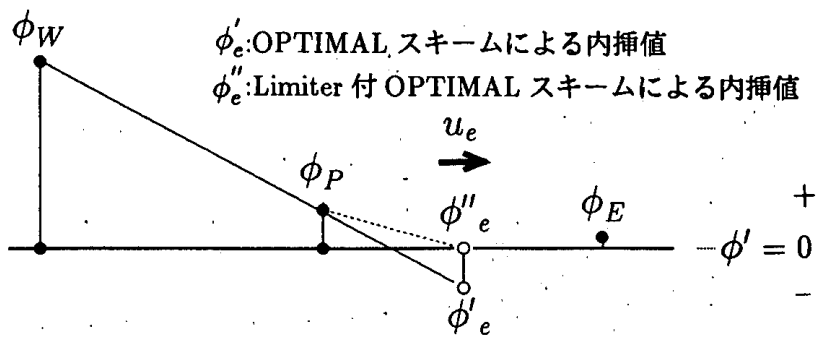

図 3 OPTIMAL スキームの Limiter

追加すれば CF は局所セルペクレ数を用いて以下のよう に一意的に决定できる。

$C F_{\mathrm{i}}=\max \left(0, \frac{1}{2}-\frac{1}{\left|\mathrm{Pe}_{\mathrm{i}}\right|}\right)$

ただし $, C F_{i}=0 \quad,\left(\left|P e_{i}\right|=0\right)$

OPTIMAL スキームでは，隣接係数の符号は常に正ま たは 0 となることを条件にCF を决定しているが,これ は，セルペクレ数の絶対值が 2 以下の場合は中心差分近 似とし，それ以上ではセルペクレ数の分布状況に応じて QUICK を経由して最終的に 2 次精度風上スキームとな るよう内㧴法の風上成分への重みを対流作用の強さに応 じて連続的に調節することに相当する。

\subsection{OPTIMAL スキームの Limiter}

OPTIMAL スキームを実際に計算に適用すると，4章 に示すように 2 次風上系スキーム単独の場合に比へ, "wiggling"等の問題は大幅に緩和される。しかし，先に 述べたように $a_{W W}, a_{E E} に は$ 依然として負の值が残るた めに，問題によってはわずかながらアンダー/オーバー シュートが生じる場合がある。

そこで CV 界面の内㧴値に関し，図 3 に示すように Limiter を作用させる対策を講じる。つまり, 内挿值 $\phi^{\prime}$ に関する物理的な許容範囲を $\phi_{\min } \leq \phi^{\prime} \leq \phi_{\max }$ とし, こ の範囲を逸脱する場合は内抙値を許容範囲の上限下限值 で置き換える。実際の計算アルゴリスムとしては，陽解 法を用いる場合は flux 計算段階で，陰解法による収束計 “算を行う場合は予め内㨉值を求めた上で, Limiter を作 用させる部分についてのみ係数を変更すれば良い。上記 方法を用いた場合, 本報に示す全ての計算条件では，ア ンダーノオーバーシュートは回避可能であった。 


\section{4. 定常湿度計算における各スキームの特性}

先に述へた新開発 OPTIMAL スキームと既往の移流 項スキームの実用問題での特性を比較検討するため，等 分割の $36 \times 36$ mesh 及び不等分割の $41 \times 41$ mesh を用 いた 2 次元濃度分布の計算を行った。想定気流場は 288 $\times 288$ mesh の等分割を用いて生成したものであり，同 一詳細 mesh における濃度計算結果を比較用の基準解と して用いた。

\section{1 層流計算結果}

\section{(1) 計算条件}

吹出し・吸込み幅 1 の $9 \times 9$ の正方形領域を対象とし, 等分割の $288 \times 288 \mathrm{mesh}$ により 2 次元首流計算を行っ た。計算条件として，吹出し Re 数に 100 , 吹出し・吸 込み法線方向速度を境界上で 1 , 接線方向の速度を仮想 セルで 0 とし，壁境界条件は no-slip 条件を用いた。使 用差分近似式は，運動方程式の移流項に QUICK，他は 中心差分とし, 解法は ABMAC 法に準じた。図 4 に気 流計算結果を示す。濃度計算は差分スキームの影響が顥 在化し易い条件として, 主流中の 64 セル $(36 \times 36$ 分割 の $1 \mathrm{mesh}$ 分に相当，図 4 参照) が濃度発生点となる条件 を想定し，吹出濃度 flux を 0 とし，壁境界条件として free-slip 条件を用いた。解法は逐次緩和法による陰解法, 収束判定条件は最大残差を $1 \times 10^{-5}$ とした。

\section{(2) 詳細 mesh の計算結果}

気流計算に用いた $288 \times 288$ 詳細 mesh 分割を用い, QUICK 及び hybrid スキーム7) を用いて濃度分布を求 めた。計算濃度分布は図 5 に示すように hybrid では QUICK より右上部で若干高濃度となるが，両者は全般 的によく対応し, 表 1 に示すように平均濃度, 最大值に ついてもよく一致することから, 詳細 mesh では差分ス キームによる差はほぼ無視できると考えられる。

\section{(3) $36 \times 36$ 等分割の計算結果}

詳細 mesh による気流計算結果を $36 \times 36$ mesh に平 均化した流れ場を用いて濃度分布を計算した。図 6 に 平均された流れ場のセルペクレ数の分布を示す。検討ス キームは表 2 に示すように, 1 次風上系 3 通り,2 次風上 系 6 通り,LODA 系 3 通り, ULTRA-SHARP 及び OPTIMAL 系 2 通りの計 15 種類である。計算濃度分布の 一部を図 7 に, 平均濃度, 最大值, 最小值を表 2 にまと めて示す。各スキームによる計算解の特徽は以下となる。 a. 1 次風上系スキーム スキーム間の差は小さいが, い ずれも拡散が過大評価され, 平均濃度は詳細 mesh の 3 倍以上大きい值となる。

b. 2 次風上系スキーム スキームの差が顥在化し, CF が小さいほど拉散が小さく評価されるもののアンダー シュートは大きくなる。2 次風上スキームを用いても負 の濃度は解消されない。
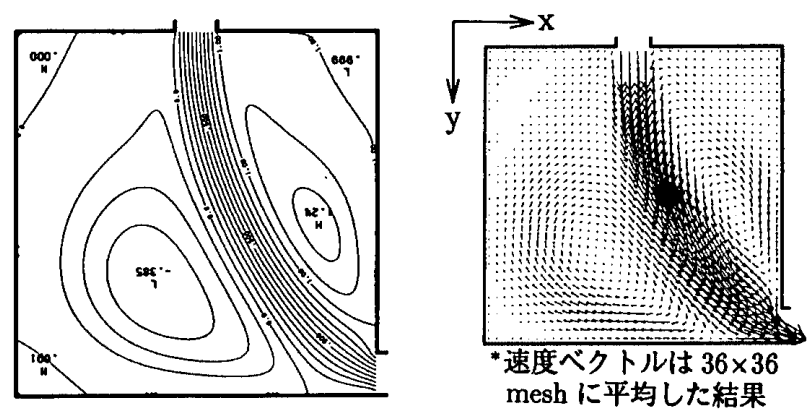

図 4 気流計算結果及び濃度発生点

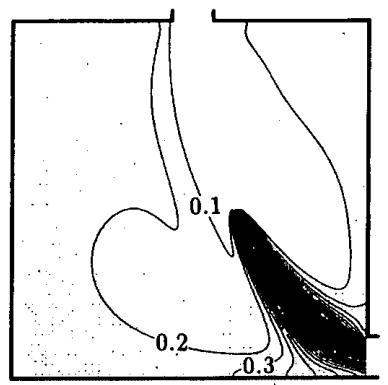

a)hybrid

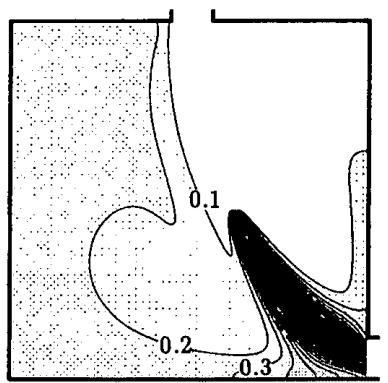

b)QUICK
図 $5288 \times 288$ 分割 mesh による空間濃度分布

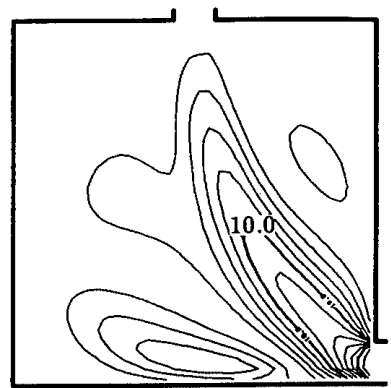

a) $P e_{x}$

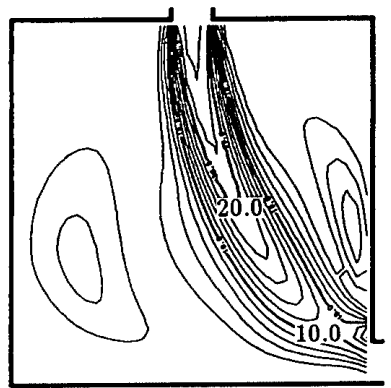

b) $P e_{y}$
図 6 平均流れ場のセルペクレ数の分布

表 $1288 \times 288$ 詳細 mesh による濃度計算結果 $(R e=100)$

\begin{tabular}{|c|r|r|r|}
\hline 空間差分近似式 & 平均港度 & ${\text { 最大値 }{ }^{+1)}}$ & 最小值 \\
\hline hybrid スキーム & 0.232005 & 2.873179 & 0.000000 \\
\hline QUICK スキーム & 0.231783 & 2.903383 & 0.000000 \\
\hline
\end{tabular}

*1)最大値は $36 \times 36 \mathrm{mesh}$ 分割に平均した結果

表 $236 \times 36$ 等分割 mesh による濃度計算結果 $(R e=100)$

\begin{tabular}{|c|c|c|c|c|}
\hline \multicolumn{2}{|c|}{ 空間差分近似式 } & 平均港度 & 最大值 & 最小值 \\
\hline \multirow{3}{*}{1 次風上系 } & 1 次風上 & 0.726396 & 3.246998 & 0.00011 \\
\hline & hybrid & 0.708181 & 3.413151 & 0.00000 \\
\hline & PLDS & 0.703359 & 3.415608 & 0.00008 \\
\hline \multirow{6}{*}{$\begin{array}{l}2 \text { 次風上系 } \\
(\mathrm{CF}=)\end{array}$} & 0.0 & 0.088959 & 5.063670 & -3.40310 \\
\hline & 0.0625 & 0.139645 & 4.176262 & -1.75879 \\
\hline & 0.125 & 0.193733 & 3.607216 & -1.01479 \\
\hline & 0.250 & 0.280082 & 2.886627 & -0.36355 \\
\hline & 0.375 & 0.343164 & 2.451881 & -0.08838 \\
\hline & 0.5 & 0.391231 & 2.162060 & -0.00716 \\
\hline \multirow{3}{*}{ LODA 系 } & 無条件 & 0.695159 & 3.332445 & -0.00046 \\
\hline & 条件付 & 0.327966 & 3.296927 & -0.00028 \\
\hline & 条件付+1 欢 & 0.326098 & 3.296218 & 0.00003 \\
\hline \multicolumn{2}{|c|}{ ULTRA-SHARP } & 0.486509 & 3.992536 & 0.00003 \\
\hline \multirow[t]{2}{*}{ OPTIMAL } & 無条件 & 0.351395 & 2.313630 & -0.00097 \\
\hline & Limiter 付 & 0.355001 & 2.313443 & 0.00000 \\
\hline
\end{tabular}




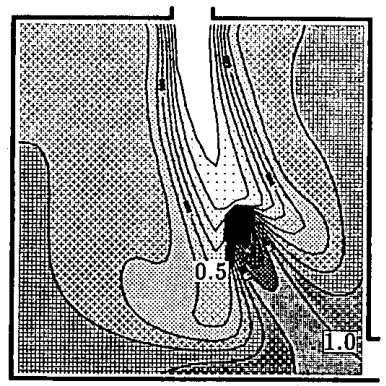

a) 1 次風上

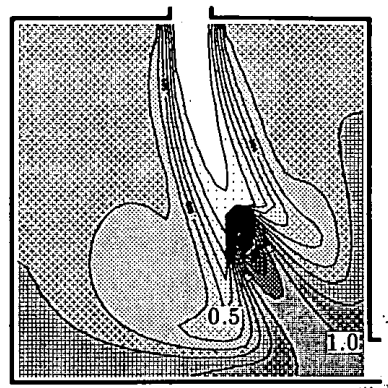

b)hybrid

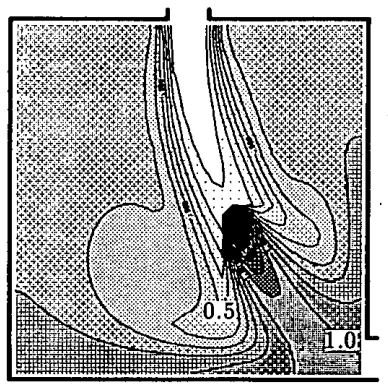

c)PLDS

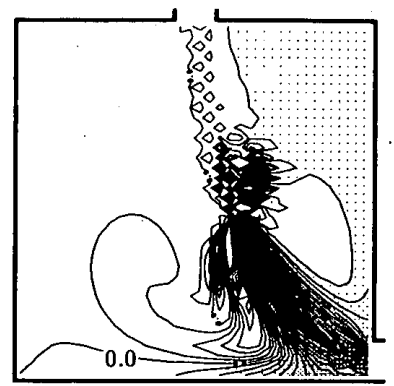

d) 中心差分 $(\mathrm{CF}=0)$

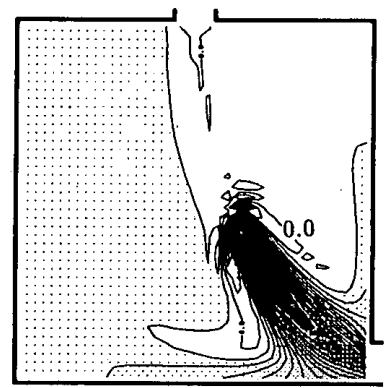

e)QUICK $(\mathrm{CF}=0.125)$

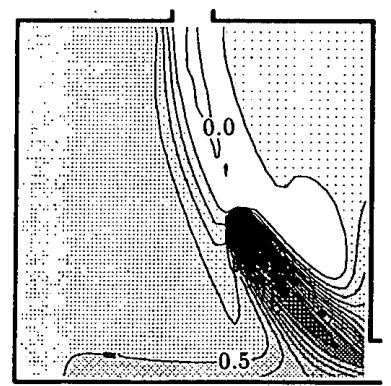

f)2 次風上 $(\mathrm{CF}=0.5)$

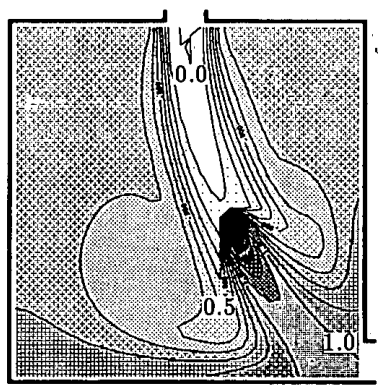

g) 無条件 LODA

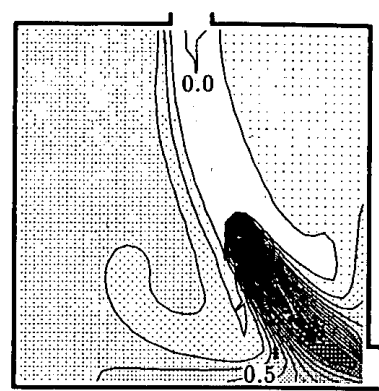

h) 条件付 LODA

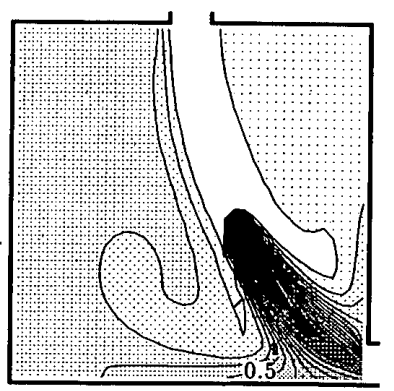

i) 条件付 $\mathrm{LODA}^{+1}$ 次風上

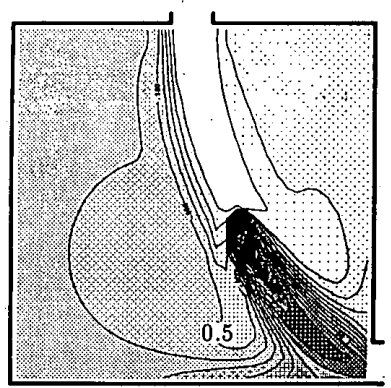

j) ULTRA-SHARP

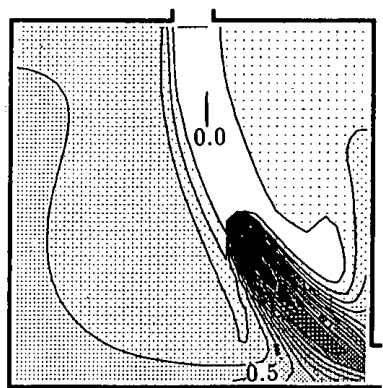

k) 無条件 OPTIMAL

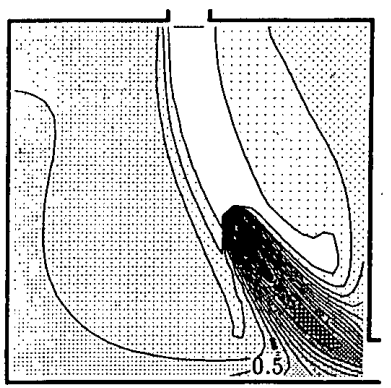

1) 条件付 OPTIMAL

図 $736 \times 36$ 等分割 mesh による空間濃度分布

c. LODA 法 無条件 LODA は PLDS ${ }^{8}$ の結果に近く, 拡散過大である。条件付 LODA では数値拡散は抑制され るが, 依然として吹出し直下が負の濃度となること注 1), SOR 法による収束過程の安定化のために極端な減速緩 和注 2)を要すること等の問題がある。吹出口直下の負の 濃度は吹出口周辺を強制的に 1 次風上スキームとするこ とで解消される。

d. ULTRA-SHARP スキーム 負の濃度は生じない が，平均濃度は詳細 mesh よりも約 2 倍大きくなること， 条件付 LODA 亡同様に収束が困難となり, 極端な減速 緩和注 2)をせざるを得ない等の問題がある。

e. OPTIMAL スキーム 内㨉値に Limiterを用いない 場合，吹出し直下にわずかな負の濃度が現れるが，Limiter 作用させることで解消される。平均濃度は条件付 LODA と同程度であり詳細 mesh より 5 割程度大きい。 計算安定性は極めて良く, 収束計算時間は 2 次風上系ス キームと同程度となる。図 8 に定常時の CF の分布を示す が, セルペクレ数が大きい主流域ではほぼ 2 次精度風上 $(\mathrm{CF}=0.5)$ で, 両側の渦近傍では QUICK $(\mathrm{CF}=0.125)$ で, その他の領域では中心差分スキーム $(\mathrm{CF}=0)$ で計算され ており，セルペクレ数と同様な分布の傾向を見せている。

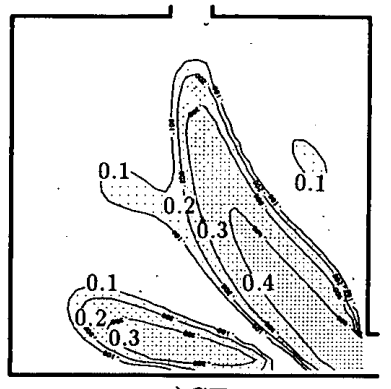

a) $\mathrm{CF}_{x}$

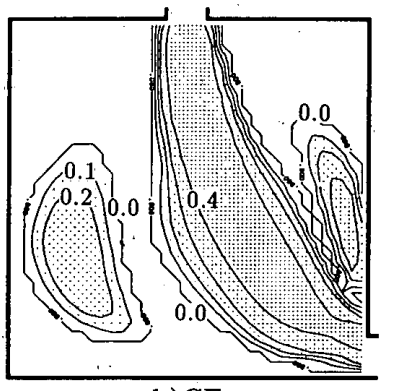

b) $\mathrm{CF}_{y}$
図 8 OPTIMAL スキームにおける定常時の CF の分布

\section{(4) $41 \times 41$ 不等分割による計算結果}

負の濃度が回避可能なズキームの中では, OPTIMAL や条件付 LODA の結果が比較的良好であるが, 平均濃 度はいずれも詳細 mesh 解に比へてて大きい。図 5-(a)の hybrid による詳細 mesh 解を $36 \times 36$ 分割に平均化し, OPTIMAL を作用させて相対打切誤差を求めたところ 図 9 示すように濃度発生点付近で大きくなった。そこで, この部分を細分割した図 10 の mesh を用い，先に用い た主要なスキームによる計算を行い，分割の相違による 影響を検討した。計算濃度分布を図 11 に，平均濃度等 を表 $3 に$ 示す。 
表 $341 \times 41$ 不等分割 mesh による濃度計算結果 $(\mathrm{Re}=100)$

\begin{tabular}{|c|c|c|c|c|}
\hline 空間差分近似式 & 平均灙度 & 最大值・1) & 最小侹 & 比較 \\
\hline 1次風上 & 0.664353 & 2.357284 & 0.00011 & 2.86 \\
\hline QUICK & 0.253770 & 2.315732 & -0.23055 & 1.09 \\
\hline 2 次風上 & 0.260143 & 2.008443 & -0.12236 & 1.12 \\
\hline 条件付 LODA ${ }^{+1} \delta / 2$ & 0.264394 & 2.273890 & 0.00002 & 1.14 \\
\hline ULTRA-SHARP & 0.388123 & 2.225826 & 0.00003 & 1.67 \\
\hline 条件付 OPTIMAL & 0.248151 & 2.155062 & 0.00000 & 1.07 \\
\hline
\end{tabular}

-1)最大值は $36 \times 36 \mathrm{mesh}$ 分割に平均した結果

•2)詳細 mesh による hybrid の計算結果との比䖝

a. 1 次風上スキーム 平均濃度は若干低下するが全般 的に顥著な変化は認められない。1 次風上スキームでは mesh の細分化による効果はそしい。

b. 2 次風上系スキーム 濃度分布の傾向は詳細 mesh と かなり近くなり，アンダーシュートも緩和されるが負の 濃度は避けられない。

c. LODA 法 顥著な改善が認められるが, 負の濃度を 回避するために部分的な 1 次精度風上を要すること, 収 束が困難なことは先と同様である。

d. ULTRA-SHARP スキーム平均濃度は詳細 mesh に近づくが, 依然として詳紐 mesh より 7 割程度の過大 評価となる。

e. OPTIMAL スキーム 濃度分布, 平均値, 最大值 ともに，詳細 mesh による解と極めてよく対応するとと もに，収束計算は極めて容易である。

\section{2 乱流計算結果}

\section{(1) 計算条件}

計算領域, mesh 分割は層流と同様であり, 壁境界条 件は $1 / 7$ 乗風速分布の仮定に基つくく壁関数を用いた。使 用差分近似式としては, 運動方程式, $\mathrm{k}, \varepsilon$ 式の移流項に QUICK(ただし， $\varepsilon$ は部分 1 次風上使用), 他は中心差分 とした。図 12 に- $\varepsilon$ モデルよる乱流計算を行った結果 を示す。濃度計算条件, 解法等はすべて層流計算と同様 である。

\section{（2）詳細 mesh による部算轺果}

濃度発生点を層流の場合と同一とし, QUICK 及びhybrid による濃度分布計算を行った結果を図 13 , 表 4 に 示す。QUICK ではソース発生源の直上部で負の濃度が 発生し, hybrid による平均濃度は QUICK より 2 割程度 大きく計算される等, スキームによる差が顥在化してい る。これは，乱流では空間分割が未だ不十分であること を示唆するものの, 全般的な分布は比較的類似している ことからこれらを比較用の基準解として用いた。

\section{(3) $36 \times 36$ 等分割の計算結果}

詳細 mesh による気流計算結果 (流れ場及び渦動粘性 係数) を $36 \times 36 \mathrm{mesh}$ に平均化し (図 14 に平均流れ場の セルペクレ数の分布を示す), 空間濃度の計算を行った。 計算結果を表 5 及び濃度分布の一部を図 15 に示す。

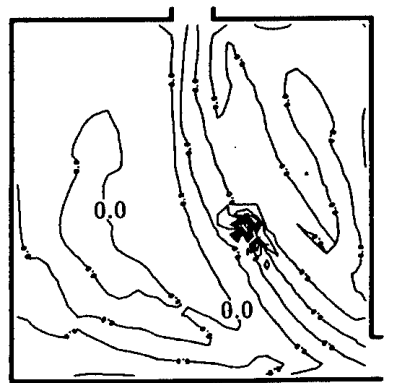

図 9 打切り愦差分布 (OPTIMAL)

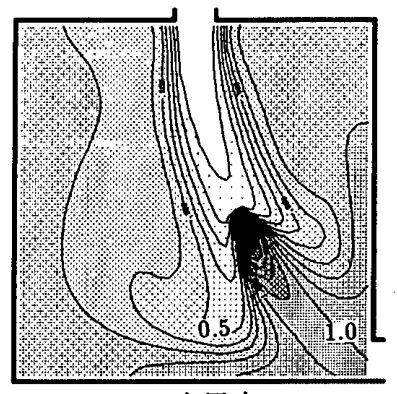

a)1 次風上

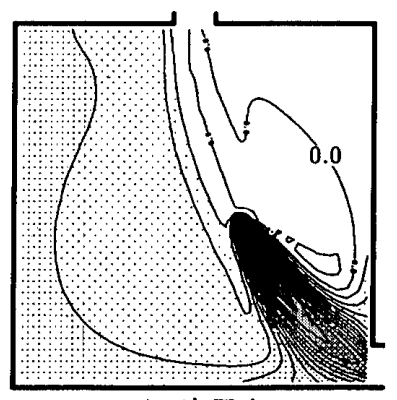

c)2 次風上

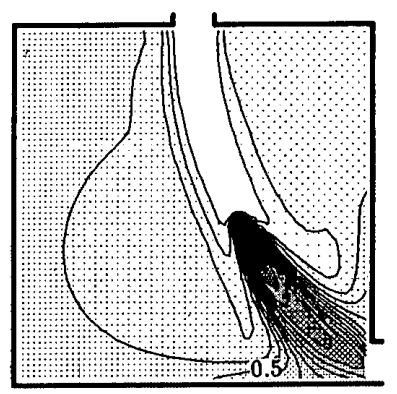

e)ULTRA-SHARP

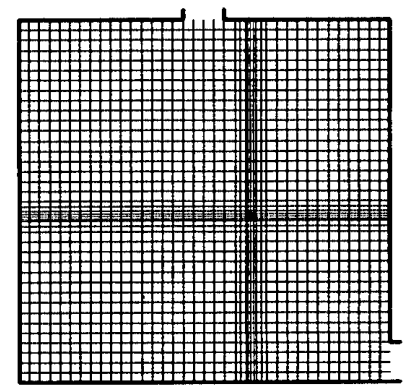

図 10 不等分割 mesh

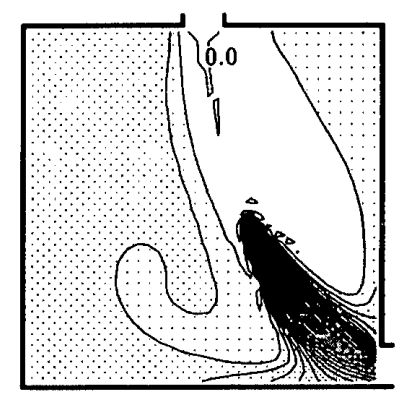

b)QUICK

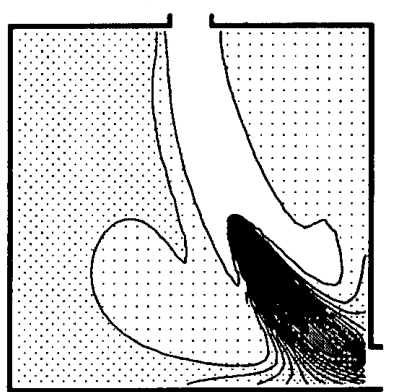

d) 条件付 $\mathrm{LODA}^{+1}$ 饮而上

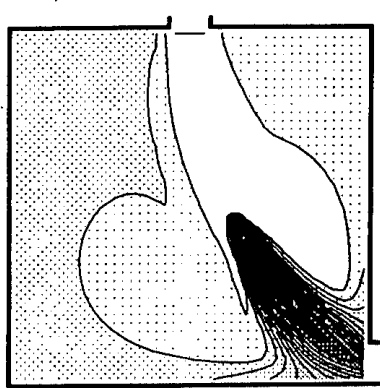

f) 条件付 OPTIMAL
図 $1141 \times 41$ 不等分割 mesh による空間濃度分布

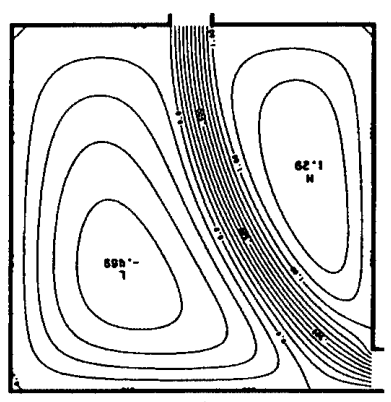

a) 流線

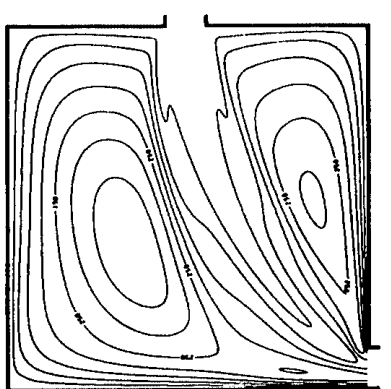

b) 渦動粘性係数
図 12 乱流計算結果 
表 $4288 \times 288$ 詳細 mesh による濃度計算結果

\begin{tabular}{|c|r|r|r|}
\hline 空間差分近似式 & 平均浱度 & 最大値 $^{* 1)}$ & 最小値 \\
\hline hybrid スキーム & 0.358085 & 2.734762 & 0.000000 \\
\hline QUICK スキーム & 0.305162 & 3.129004 & -0.100380 \\
\hline
\end{tabular}

*1)最大值は $36 \times 36 \mathrm{mesh}$ 分割に平均した結果

表 $536 \times 36$ 等分割 mesh による濃度計算結果

\begin{tabular}{|c|c|c|c|c|}
\hline \multicolumn{2}{|c|}{ 空間差分近似式 } & 平均灙度 & 最大値 & 最小值 \\
\hline \multirow{3}{*}{1 次風上系 } & 1 次風上 & 0.763189 & 3.044915 & 0.00001 \\
\hline & hybrid & 0.755421 & 3.077571 & 0.00000 \\
\hline & PLDS & 0.752496 & 3.078965 & 0.00000 \\
\hline \multirow{6}{*}{$\begin{array}{l}2 \text { 次風上系 } \\
(\mathrm{CF}=)\end{array}$} & 0.0 & 0.415569 & 4.615625 & -3.83930 \\
\hline & 0.0625 & 0.371835 & 3.839427 & -1.92942 \\
\hline & 0.125 & 0.390088 & 3.319928 & -1.10489 \\
\hline & 0.250 & 0.456030 & 2.639191 & -0.41646 \\
\hline & 0.375 & 0.507022 & 2.238659 & -0.13552 \\
\hline & 0.5 & 0.541332 & 1.981359 & -0.04345 \\
\hline \multirow{3}{*}{ LODA 系 } & 無条件 & 0.746921 & 3.049489 & -0.00374 \\
\hline & 条件付 & 0.499633 & 2.982042 & -0.00290 \\
\hline & 案件付 +1 欢風上 & 0.497578 & 2.983131 & 0.00000 \\
\hline \multicolumn{2}{|c|}{ ULTRA-SHARP } & 0.748356 & 3.720526 & 0.00000 \\
\hline \multirow{2}{*}{ OPTIMAL } & 無条件 & 0.543286 & 2.009144 & -0.03991 \\
\hline & Limiter 付 & 0.456748 & 2.664873 & 0.00003 \\
\hline
\end{tabular}

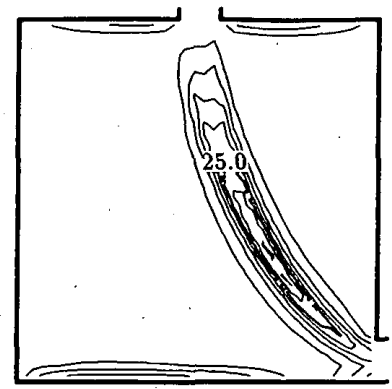

a) $\bar{P} e_{x}$

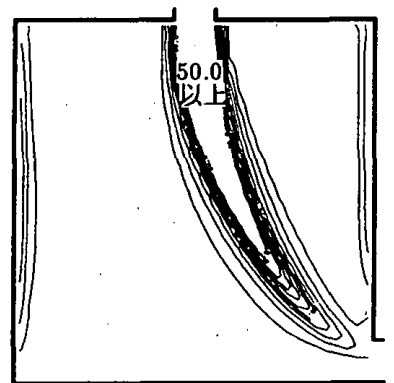

b) $P e_{y}$
図 14 平均流れ場のセルペクレ数の分布

a. 1 次風上系スキーム スキーム間の差は小さく，搪 散過大である。平均濃度は詳細 mesh 解より 2 倍以上大 きくなる。

b. 2 次風上系スキーム アンダーシュートが首流の場合 よりも大きくなり，負の濃度が発生する領域も広かる。 c. LODA 法 部分 1 次風上併用の条件付 LODA では負 の濃度の発生はなく, 分布の傾向も詳細 mesh の hybrid にかなり近い。ただし，平均濃度は 4 割程度大きい。収 束計算は首流の場合よりも難しくなる。

d. ULTRA-SHARP スキーム 負の濃度は生じない か，平均濃度は 1 次風上系と同様，詳細 mesh 解の 2 倍 程度の大きい值となり，乱流；粗 mesh 条件では影著な 精度向上は望めない。

e. OPTIMAL スキーム Limiter 付では負の濃度は現 れない。分布の傾向は詳細 mesh 解にかなり近いが，平 均濃度は 3 割程度過大評価之なる。図 16 に定常時の CF の分布を示すが，首流計算結果と同じくセルペクレ数の 分布状況に応じてスキームが選択されていることが分か る。乱流条件においても収束計算は極めて良い。

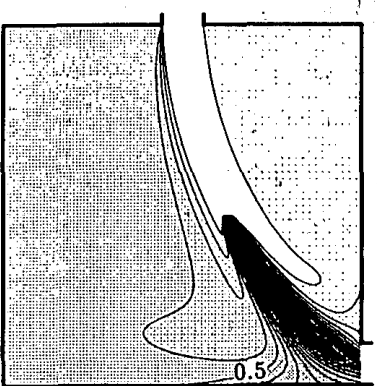

a)hybrid

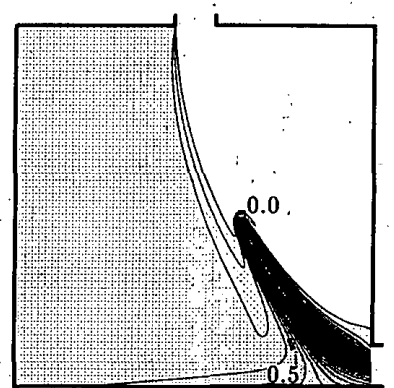

b)QUICK
図 $13288 \times 288$ 分割 mesh.による空間濃度分布

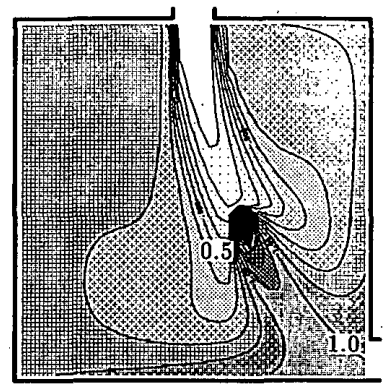

a) 1 次風上

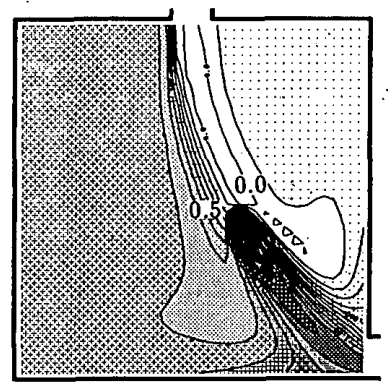

c)2 次風上

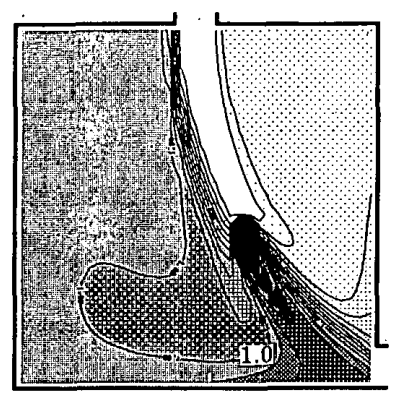

e)ULTRA-SHARP

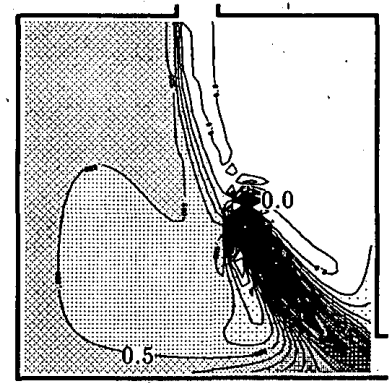

b)QUICK

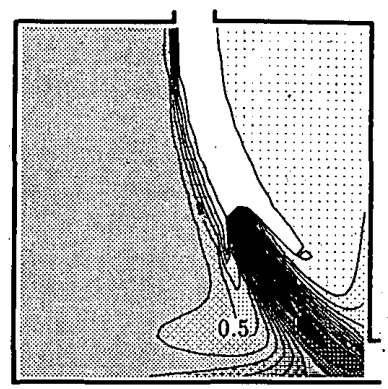

d) 条件付 LODA+1 狄風上

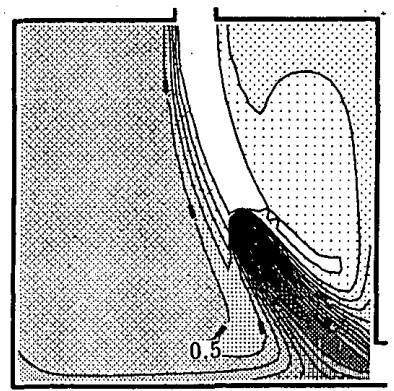

f) 条件付 OPTIMAL
図 $1536 \times 36$ 等分割 mesh による空間濃度分布

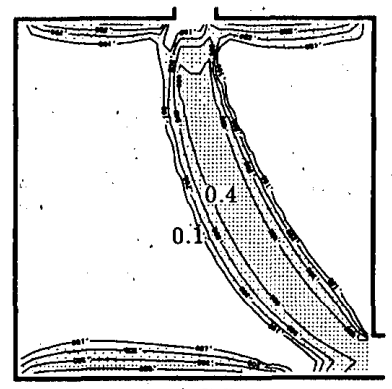

a) $\mathrm{CF}_{x}$

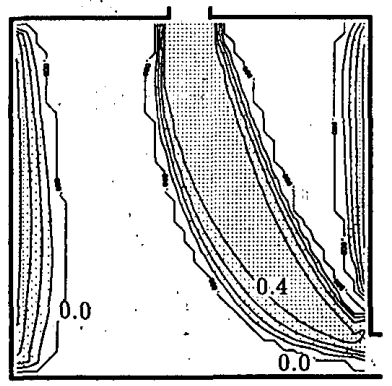

b) $\mathrm{CF}_{y}$
図 16 OPTIMAL スキームにおける定常時の CF の分布 


\section{(4) $41 \times 41$ 不等分割による計算結果}

打切り誤差解析結果は層流と同様の結果となったので (図省略)，図 10 の mesh 分割による濃度計算を行った。 計算濃度分布を図 17 に，平均濃度等を表 6 に示す。

a. 1 次風上スキーム 首流計算結果と同じく， mesh の 細分化による効果は小さい。

b. 2 次風上系スキーム 濃度分布の傾向は詳細 mesh に 近いか，負の濃度が生じる領域は主流の右側に広範囲に 広がる。

c. LODA 法 解の許容範囲の最適化，1 次風上の使用 領域を適切に行えば，詳細 mesh の hybrid と良好に対応 する計算結果が得られる。

d. UHTRA-SHIRP スキーム 平均濃度の過大評価 は緩和されるか，依然として 6 割程度大きい值となる。 e. OPTIMAL スキーム 最適な LODA とほぼ同等の 解となり，詳細 meshによる結果にかなり近い。

\section{5. 非定常湜度計算結果}

4 章の定常濃度計算結果を見ると, 首流, 乱流条件とも に, OPTIMAL スキーム及び LODA 法が優れていると 判断される。しかし，LODA では負の濃度を回避すると 共に，数值拡散を抑制するための最適な解の許容範囲の 条件設定, 部分的に 1 次風上スキームの適用を要するこ と，収束性が悪いこと等の問題がある。更に，LODA は 陰解法を原則として提案されており，非定常濃度計算に は直接に使えない。これらの点を考慮すると，実用計算 ではより簡便かつ安定性に優れた OPTIMAL が推奖て きる。そこで, 同スキームの具体的な応用例として, 吹 出し空気の平均到達時間を意味する局所平均年齢 (Local Age of air, 以下 LA) の空間分布の算出を試みた。トレー サーステップアップ法を想定した場合の LA の計算式は 以下となる9)。

$\overline{\tau_{P}}=\int_{0}^{\infty}\left(1-\frac{C_{P}(t)}{C_{S}}\right) d t$

LA の空間分布の計算に先立って，図 18 に示す 3 通り

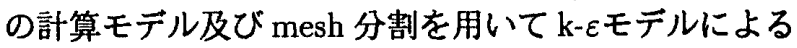

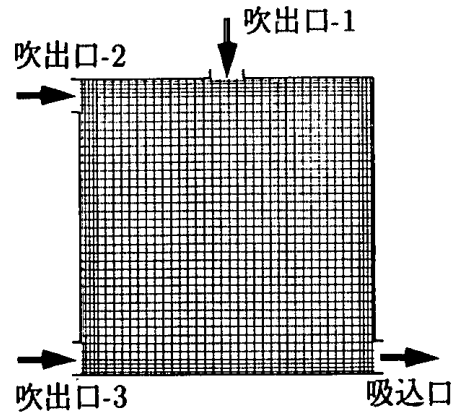

図 18 非定常濃度の計算モテル 及び mesh 分割
表 $641 \times 41$ 不等分割 mesh による濃度計算結果

\begin{tabular}{|c|c|c|c|c|}
\hline 空間差分近似式 & 平均浪度 & 最大值 ${ }^{* 1)}$ & 最小值 & 比較 \\
\hline 1 次風上 & 0.713419 & 2.193064 & 0.00002 & 1.99 \\
\hline QUICK & 0.384867 & 2.085097 & -0.28515 & 1.07 \\
\hline 2 次風上 & 0.382828 & 1.802822 & -0.16438 & 1.07 \\
\hline 条件付 LODA ${ }^{+1}$ 昷上 & 0.377258 & 2.021953 & 0.00000 & 1.05 \\
\hline ULTRA-SHARP & 0.566084 & 1.962723 & 0.00000 & 1.58 \\
\hline 条件付 OPTIMAL & 0.376845 & 1.829680 & 0.00000 & 1.05 \\
\hline
\end{tabular}

-1)䯅大值は $36 \times 36 \mathrm{mesh}$ 分割に平均した結果

*2)詳細 mesh による hybrid の計算結果との比数

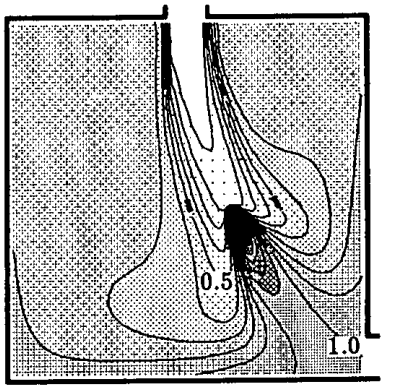

a) 1 次風上

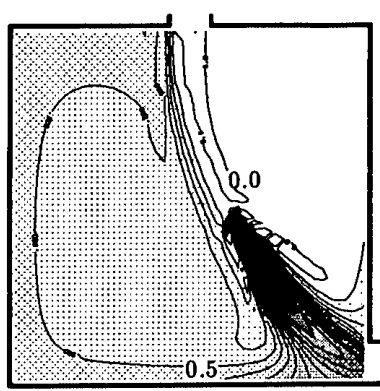

c) 2 次風上

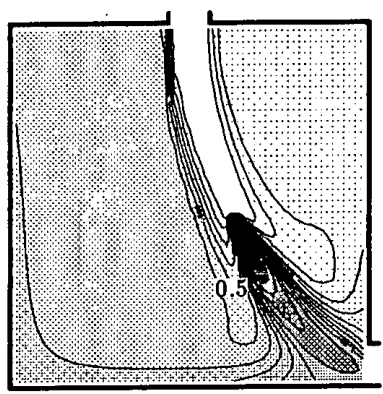

e)ULTRA-SHARP

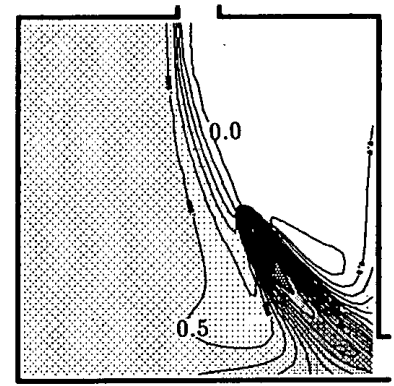

b)QUICK

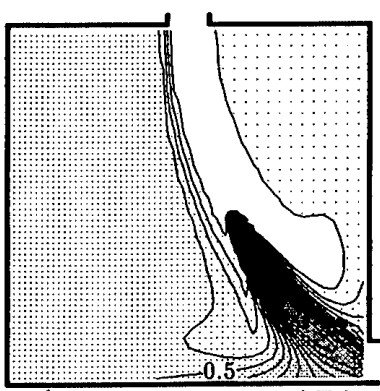

d) 条件付 $\mathrm{LODA}^{+1}$ 次風上

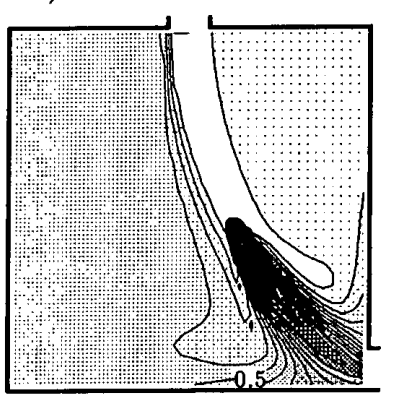

f) 条件付 OPTIMAL
図 $1741 \times 41$ 不等分割 mesh による空間濃度分布

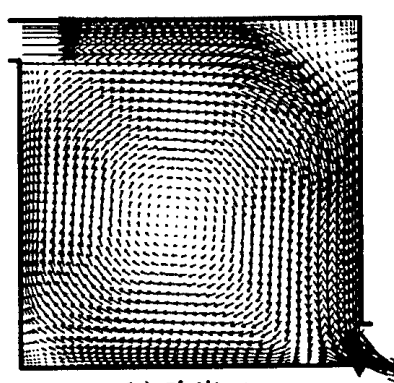

b) 吹出口-2

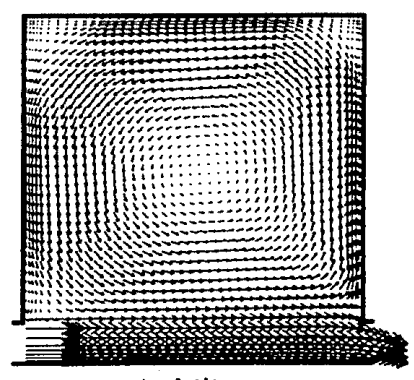

c) 吹出口-3
図 19 計算速度ベクトル 


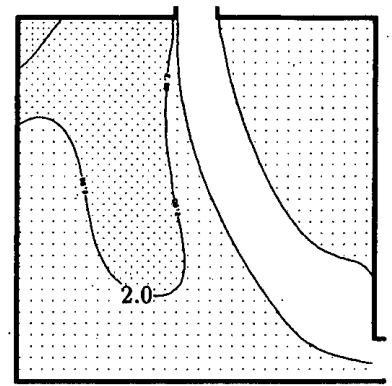

a)1 次風上

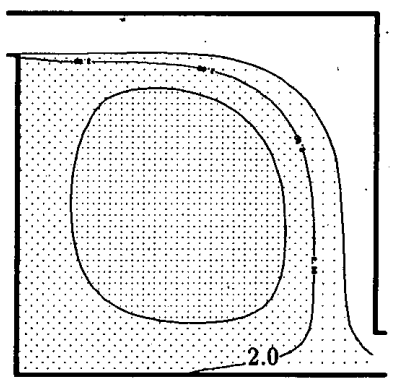

a) 1 次風上

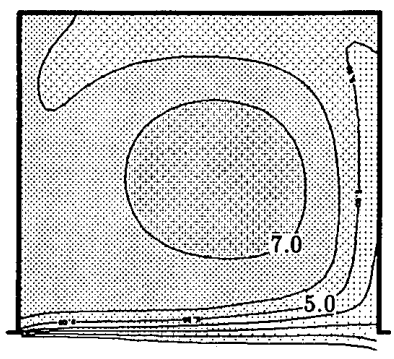

a)1 次風上

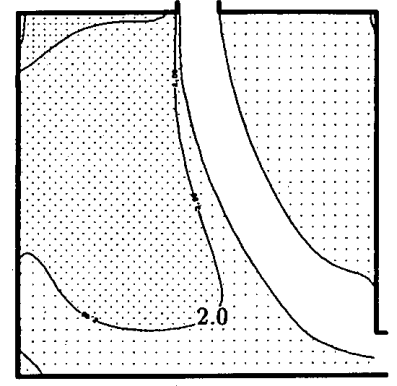

b)PLDS

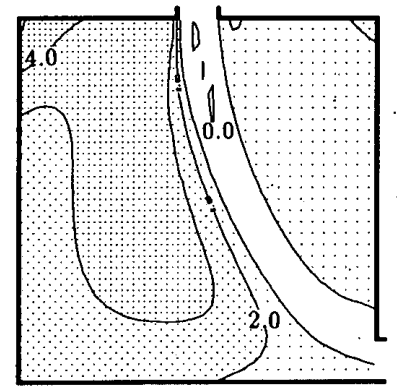

c)QUICK

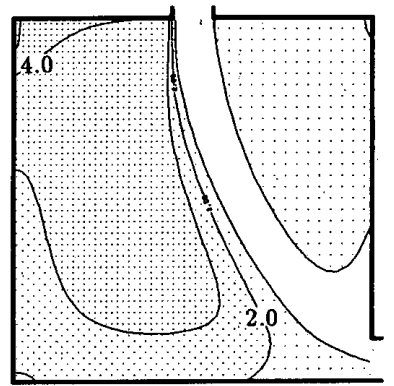

d)OPTIMAL

図 20 局所平均年夦*3)の空間分布 (吹出口-1)

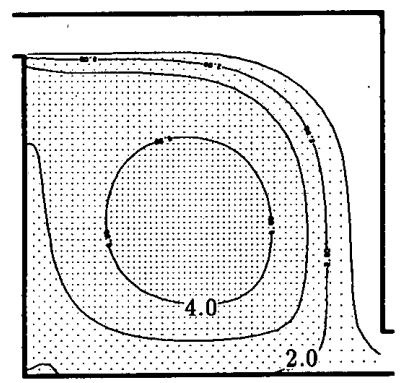

b)PLDS

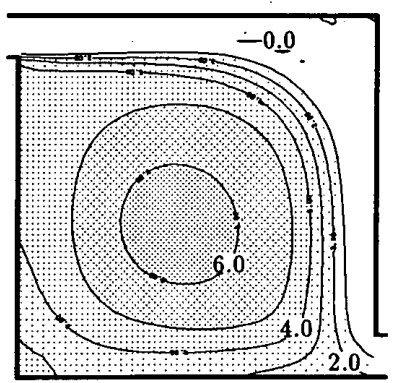

c)QUICK

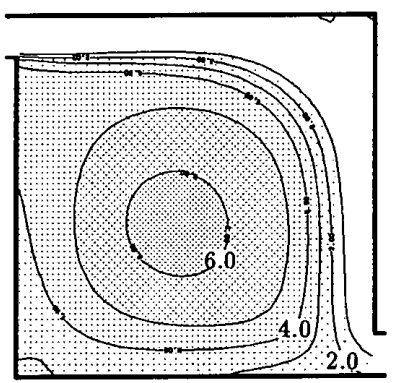

d)OPTIMAL

図 21 局所平均年齡*3) の空間分布 (吹出口-2)

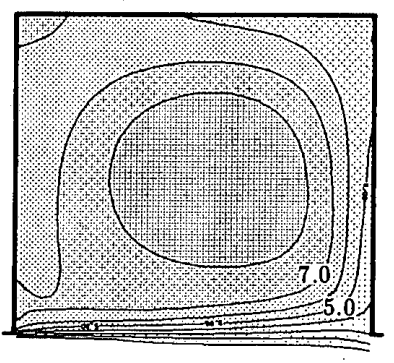

b)PLDS

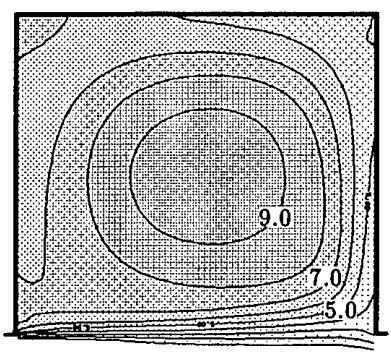

c)QUICK

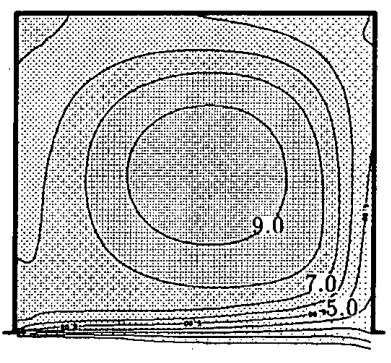

d)OPTIMAL

図 22 局所平均年昤*3)の空間分布 (吹出口-3)

*3)数值は名目換気回数の逆数で基準化した。

乱流計算を行った。計算条件等は 4 章の乱流計算と同し であるが, $\mathrm{k}, \varepsilon$ 式の移流項スキームに OPTIMAL スキ一 ムを，時間微分項は前進差分スキームを使用した。計算 した流れ場を図 19 に示すが，これを用いた非定常濃度 計算より式 34) の積分を数值的に行い，LA の空間分布 を求めた。使用スキームは Limiter 付 OPTIMAL と, 比 較用にQUICK, PLDS, 1 次風上スキームを用いた。計 算結果を図 20〜図 22 に示す。図より 1 次風上, PLDS では数值拡散が空間濃度の均一化を促進するので LA の 空間変化は小さい反面, OPTIMAL では循環領域で大 きい値となり，気流構造を反映した結果となっている。 QUICK は一部で負の値を示しているが, 全般的に室平 均年秢, 年路分布ともに OPTIMAL とほぼ同様の計算 結果となっている。但し, 各スキームによる濃度の時間 変化については図 23 に示すように, QUICK では濃度 の立上がりの時点で顕著なアンダー/オーバーシュート が生じる反面，OPTIMAL ではこれが回避されている。

\section{6. まとめ}

CV 界面值に 2 次風上系スキームの内挿法を一貫して 用いるが，風上因子を局所セルペクレ数によって最適化 することで, 2 次精度スキームに特徴的な”wiggling”等の 問題を大幅に緩和可能な新たな OPTIMAL スキームを 開発した。また，新開発OPTIMAL スキームおよび従来 の様々の差分スキームを, 2 次元層流之乱流条件の定常／ 非定常濃度拡散問題に適用し, 粗い mesh 分割の結果之 紐かい mesh 分割の結果との比較に基づき, OPTIMAL スキームの計算精度や特性について検討した。本研究で 得られた結果を以下にまとめて述へる。

1) 定常濃度の計算結果を見ると, 層流, 乱流ともに OPTIMAL スキーム及び LODA 法による結果が詳細 mesh 解によく対応したが， LODA 法では解の最適な許 容範囲の条件設定, 部分的に 1 次風上スキームの適用を 要すること, 収束性が悪いこと等の問題がある。それに 対して OPTIMAL スキームによる収束性は極めて良い。 

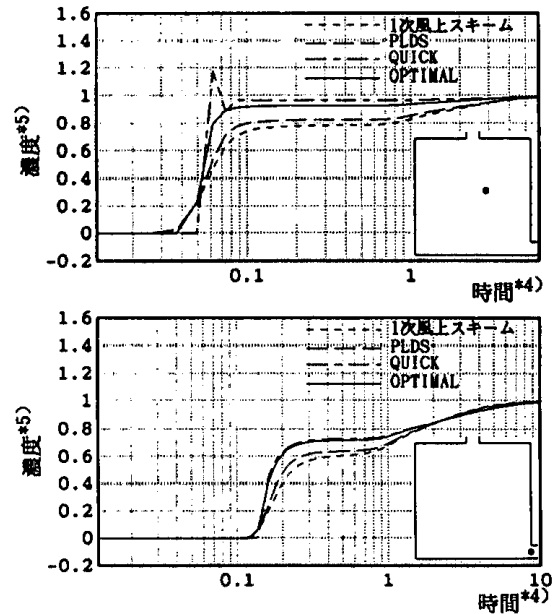

a) 吹出口-1
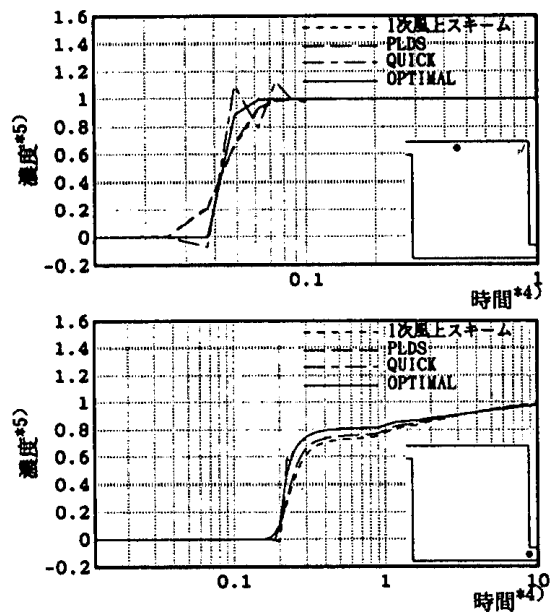

b) 吹出口-2
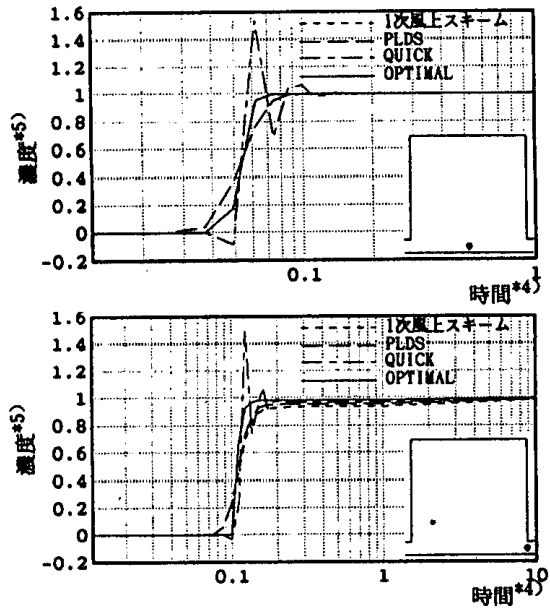

c) 吹出口-3

図 23 空間濃度の時間変化

*4)時間は名目換気回数の逆数で基準化した。

\section{2)LODA 法と異なり, OPTIMAL スキームは非定常濃} 度計算に直接適用可能なスキームであり，2 次風上系ス キームで現れる過渡期の振動を効果的に抑えることがで きる。

\section{注}

1) 条件付 LODA 法における解の許容範囲の設定が解の収束 性や計算精度に与える影響を検討するため, $\phi_{\min }$ を変化させ た計算を行った。本来この問題では $\phi_{\min }$ は 0 であるべきだが, 補図-1に示すように $\phi_{\min }=0$ とした場合, 部分的に負の濃度 が生じるとともに収束判定条件を厳しくすると, 収束解を得 るのは困難となった。 $\phi_{\min }$ を大きすることにより負が生じ る領域が減り，収束性も向上するか，これは 1 次風上を使用 する領域の拡大に伴う人工搪散の作用によるものである。本 文中に揭载した計算結果は $\phi_{\min }$ につい層流、乱流の場合に それぞれ $0.02,0.03$ と置くことにより濃度発生点直上におけ る目の澧度は回避された。しかし，吹出し直下には依然とし て負の濃度が発生した。これは補図-2に示す加重係数の分布 から明らかなように，吹出し直下の加重係数が 0.14 程度で完 全に 1 次風上に移行していないことによるものであり，この 部分を強制的に 1 次風上とする必要があった。

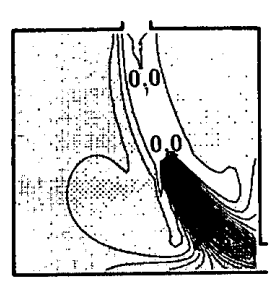

補图-1 条件付 LODA $\left(\phi_{\min }=0, R e=100\right)$
補図-2 定常時の加重係数の分布 $(R e=100)$

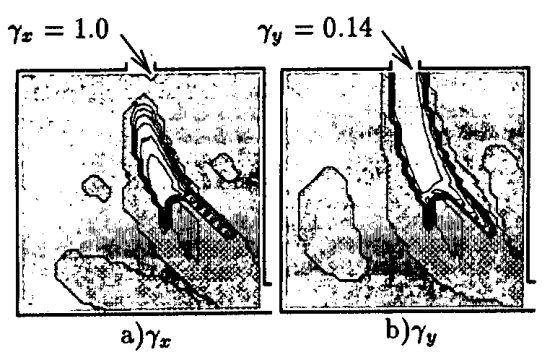

2)LODA，ULTRA-SHARP スキームでは計算安定性が悪い ため解の更新に際し，極端な減速楥和法を用いない限り収束 解は得られなかった。本論文では，減速緩和係数を 0.05 程度 にした場合，収束性は向上した。一方，一般型 2 次風上系ス キーム及び OPTIMAL では，減速紱和は不要であった。

\section{本諭文に関連する既発表文献}

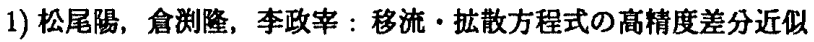
法に関する研究 (その 1)，(その 2)，(その3), 日本建筑学会大会学 術講演譚概集, pp.489-494, 1992

2)Y.Matsuo, J.J.Yee, T.Kurabuchi, M.Kamata : Highly accurate and non-oscillatory finite-difference approximation method for convection diffusion equation, Preprints for International Symposium on Room Air Convection and Ventilation Effectiveness, pp.358-365, 1992

\section{窎考文献}

1) 例えば, 貝侬正光 : 室内気流の数值解析, 空気調和 - 䚘生工学, 58-3, pp.13-24, 1984

2)J.ZHU and M.A.Leschziner : A local oscillation damping algorithm for higher-order convection schemes, Computer Methods in Applied Mechanics and Engineering (67), pp.355-366, 1988 '3)B.P.Leonard : The QUICK algorithm, A uniformly third-order finite-difference method for highly convection flows, in Computer Methods in Fluids, Pentech Press, 1980

4) 例えば，村上周三，加藤信介，須山喜美 : 室内気流数值解析の 診断システムに関する研究 (第 2 報), 移流項差分における一次精度 風上, QUICK, 中心差分スキーム等の比較検討, 日本建筑学会計 画系論文報告集, No.390, pp.1-12, 1988

5)B.P.Leonard and Simin Mokhtari : Beyond first-order upwinding, The ULTRA-SHARP alternative for non-oscillatory steadystate simulation of convection, International Journal for Numerical Methods in Engineering, VOL.30, pp.729-766, 1990

6)R.W.Benodekar, A.J.H.Goddard, A.D.Gosman and R.I. Issa : Numerical prediction of turbulent flow over surface-mounted ribs, AIAA Journal, VOL.23, NO.3, pp.359-366, 1985

7)D.B.Spalding : A novel finite difference formulation for differential expression involving both first and second derivatives, Internation journal for Numerical Methods in Engineering, VOL.4, pp.551-559, 1972

8)S.V.Patankar : Numerical heat transfer and fluid flow, Hemispere publishing corp., 1983

9)W.J.Fisk, R.J.Prill and O.Seppanen : Commercial building ventilation measurements using multiple tracer gases, Proceedings of the 9th AIVV conference, Effective Ventilation, VOL.1, pp.161182,1988

(1993 年 6 月 4 日原稿受理, 1993 年 9 月 28 日採用決定) 